\title{
EKSISTENSI DAN UPAYA MEREDUKSI PENGANGGURAN \\ DI KABUPATEN PATI
}

\section{EXISTENCE AND EFFORTS TO REDUCE THE UNEMPLOYMENT IN PATI REGENCY}

\author{
Suroso \\ Kantor Penelitian dan Pengembangan Kabupaten Pati \\ Email: suroso_peneliti@yahoo.co.id
}

Naskah Masuk: 20 September 2016 Naskah Revisi: 26 September 2016 Naskah Diterima: 5 Oktober 2016

\begin{abstract}
Unemployment is a crucial problem in the development because it can triger other social problems. The objective of this study is to analyze existing and effort to reduce the unemployment in Pati regency. The research uses descriptive-quantitative approach. The data consist of secondary data. Data collecting is conducted by using observation. The analysis uses descriptive one. There are three main findings in the research. Firstly,Unemployment is caused by many determinant factors. Secondly, the rate of unemployment based on productive age is $8,62 \%$ in the study area. Thirdly, the rate of unemployment based on head-household is $2,08 \%$ in the study area. To reduce unemployment, it is better for the local government to conduct the efforts which are relevant to the local contexts including the demand for labour, the supply of labor and the optimalization of subdistrict role in community empowerment.
\end{abstract}

Keywords: employment, labor force, unemployment.

\begin{abstract}
ABSTRAK
Penganggguran merupakan masalah serius dalam pembangunan karena pengangguran dapat memicu permasalahan sosial lainnya. Tujuan penelitian ini adalah untuk menganalisis eksistensi dan upaya pengurangan pengangguran di Kabupaten Pati. Penelitian ini menggunakan pendekatan deskriptif kuantitatif. Data penelitian menggunakan data skunder. Pengumpulan data dilakukan dengan menggunakan teknik observasi. Analisis data menggunakan analisis deskriptif. Ada 3 temuan utama dalam studi ini. Pertama, pengangguran disebabkan berbagai faktor determinan. Kedua, tingkat pengangguran berdasarkan usia produktif sebesar $8,62 \%$ di Kabupaten Pati. Ketiga, tingkat pengangguran berdasarkan kepala keluarga (KK) sebesar 2,08\% di Kabupaten Pati. Guna mereduksi pengngguran, pemerintah daerah sebaiknya melakukkan upaya yang sesuai dengan konteks lokal meliputi permintaan tenaga kerja, penyediaan tenaga kerja dan optimalisasi peran desa dalam pemberdayaan masyarakat.
\end{abstract}

Kata kunci: lapangan kerja, pengangguran, tenaga kerja 


\section{PENDAHULUAN}

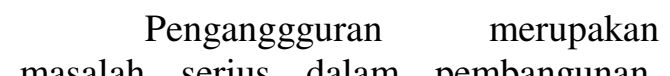
masalah serius dalam pembangunan. Penganggguran cenderung berbanding terbalik atau berkorelasi negatif terhadap ketersediaan lapangan kerja. Semakin besar ketersediaan lapangan kerja, semakin kecil potensi tingkat pengangguran. Sebaliknya semakin sedikit pertumbuhan lapangan kerja, semakin besar potensi tingkat pengangguran. Terkait lapangan kerja, Undang-Undang Dasar 1945 dalam Pasal 27 Ayat (2) menyatakan bahwa tiap-tiap warga negara berhak atas pekerjaan dan penghidupan yang layak bagi kemanusiaan. Setiap orang yang berada pada usia kerja memiliki kesempatan yang sama menjadi tenaga kerja untuk memperoleh pekerjaaan tanpa diskriminasi. UU No 13 Tahun 2003 menyatakan "tenaga kerja" adalah setiap orang yang mampu melakukan pekerjaan guna menghasilkan barang dan atau jasa baik untuk memenuhi kebutuhan sendiri maupun untuk memenuhi kebutuhan masyarakat.

Setiap warga negara berhak atas pekerjaan dan penghidupan yang layak bagi kemanusiaan tetapi kenyataan dan realitas menunjukkan bahwa sebagian orang atau penduduk sulit memperoleh pekerjaan karena lapangan kerja yang tersedia tidak sebanding dengan ketersediaan tenaga kerja sehingga sebagian terpaksa menjadi pengangguran.

Reynolds et al (1986) menyatakan pengangguran berpotensi membawa dampak pada berbagai aspek (multisektor). Aspek-aspek yang akan terkena langsung adalah kesehatan dan pendidikan, karenanya sebagian beban biaya pendidikan dan kesehatan harus ditanggung pemerintah. Bila pengangguran berlangsung cukup lama, maka kemiskinan absolut bisa meluas.
Dampak lain dari pengangguran di antaranya : (a) ketimpangan sosial, sebagian komunitas masyarakat menganggur dan sebagian lain masyarakat dapat bekerja dengan normal bahkan memperoleh penghasilan yang berlebih; (b) kecemburuan sosial, ketimpangan pendapatan, status sosial dan kekuasaan; (c) meningkatnya beban budget pemerintah untuk sektor pendidikan dan kesehatan; meningkatnya kriminalitas dan kekerasan sosial lainnya, (e) munculnya sikap permisif (serba boleh) sebagai jalan pintas untuk mempertahankan hidup; (f) potensi kendala sistem demokrasi, karena money politic lebih dominan; (g) disharmonis sistem rumah tangga, karena penopang kelangsungan rumah tangga (penghasilan) tidak memadai; meningkatnya sex komersial (pelacuran), sebagai representasi sulitnya mencari lapangan kerja; (i) melemahnya daya beli, sebagai konsekuensi langsung dari ketidakberdayaan ekonomi (rendahnya pendapatan rumah tangga); (j) Pengangguran secara tidak langsung berkaitan dengan pendapatan nasional/daerah, tingginya pengangguran menyebabkan turunnya produk domestik bruto (PDB) nasional/daerah akan mengalami penurunan; dan (k) pengangguran menghambat investasi, jumlah tabungan masyarakat ikut menurun.

Mengingat pengangguran memiliki dampak serius ke berbagai sektor maka masalah pengangguran sangat penting untuk mendapat perhatian yang serius. Berkaitan dengan harapan tersebut, studi ini memiliki tujuan untuk menganalisis eksistensi dan upaya mereduksi pengangguran di Kabupaten Pati. Hasil analisis diharapkan dapat mendukung 
kebijakan dan menanggulangi penganggguran di Kabupaten Pati.

\section{TINJAUAN PUSTAKA}

\section{Pengertian dan Determinan Pengangguran}

Pengertian "Pengangguran" adalah seseorang yang sudah digolongkan dalam angkatan kerja, yang secara aktif sedang mencari pekerjaan pada suatu tingkat upah tertentu, tetapi tidak dapat memperoleh pekerjaan yang diinginkan (Sukirno, 2004). Pengangguran dapat terjadi karena berbagai faktor determinan. Pertama, pengangguran disebabkan perubahan struktural. Menurut Reynolds et al (1986), jenis pengangguran ini terjadi karena mismatch (tak sepadan/ketidakcocokan) antara kualifikasi pekerja yang membutuhkan pekerjaan dengan persyaratan yang diinginkan. Hal ini biasanya terjadi karena adanya perubahan struktur ekonomi. Struktur ekonomi dapat diamati dari dominasi kontribusi sektoral terhadap produksi nasional (regional). Bila sektor industri memberikan kontribusi paling besar terhadap PDB dibanding dengan sektor lainnya, maka struktur perekonomian tersebut membutuhkan tenaga kerja paling besar (Sukirno, 1985). Suatu negara atau daerah terjadi pergeseran struktur ekonomi dari sektor pertanian ke industri. Dampak selanjutnya, adalah dibutuhkannya kualifikasi tenaga kerja yang cocok di sektor tersebut. Ketika persyaratan ini tidak terpenuhi (mismatch), maka tenaga kerja yang tersedia tidak terpakai, kecuali ada penyesuaian kualifikasi sesuai kebutuhan.

Kedua, adanya hambatan (ketidaklancaran) bertemunya pencari kerja dan lowongan kerja (pengangguran friksional). Jenis pengangguran ini biasanya terjadi karena hambatan teknis (misalnya waktu dan tempat). Sering terjadi pencari kerja tidak memiliki informasi yang memadai tentang lowongan kerja yang tersedia, sehingga mereka kehilangan kesempatan untuk memenuhi lowongan kerja tersebut. Mungkin juga karena situasi kerja (tempat) yang ditempati tidak cocok dengan harapan si pencari kerja, sehingga membuat pudarnya semangat kerja. Pengangguran jenis ini bisa juga terjadi karena perkembangan (dinamika) ekonomi yang terus berubah sehingga membawa dampak terhadap permintaan tenaga kerja. Artinya, situasi demikian sangat dibutuhkan tenaga kerja yang mampu mengikuti perubahan jaman dengan cepat serta mampu melakukan adaptasi keahlian terhadap tuntutan lingkungan eksternal yang dinamis tersebut. Bila situasi ini tidak bisa diikutinya, maka ia akan kehilangan kesempatan kerja (Sukirno, 1985).

Ketiga, rendahnya aliran investasi. Investasi merupakan komponen aggregate demand yang mempunyai daya ungkit terhadap perluasan kesempatan kerja. Melalui mekanisme efek multiplier, perubahan investasi membawa dampak terhadap kenaikan output. Ada beberapa faktor yang mempunyai dampak terhadap meningkatnya output yaitu pengeluaran konsumsi otonom, investasi otonom, pengeluaran pemerintah dan ekspor (Gordon, 1993). Secara otomatis meningkatnya output akan membutuhkan sumberdaya untuk proses produksi (modal, tenaga kerja dan input lainnya). Dengan demikian permintaan tenaga kerja akan meningkat ketika terjadi peningkatan dalam pengeluaran otonom. Hubungan antara kenaikan output dengan permintaan tenaga kerja (penyerapan tenaga kerja) dapat dijelaskan dengan konsep elastisitas 
penyerapan tenaga kerja (Simanjuntak, 1985).

Keempat, rendahnya tingkat keahlian. Keahlian dan produktifitas sangat berkaitan erat. Tenaga kerja yang memiliki keahlian akan memiliki produktifitas tinggi, karena ia mampu memanfaatkan potensi dirinya dalam kegiatan ekonomi produktif. Guna meningkatkan keahlian dapat dilakukan berbagai cara, diantaranya adalah melalui pendidikan dan latihan, magang, pendidikan formal, dan untuk membangkitkan kecerdasan tenaga kerja lewat pembinaan motivasi kerja dan corporate learning (percepatan belajar perusahaan) (Reynolds et al, 1986; Rose and Nicholl, 2002).

Kelima, diskriminasi. Diskriminasi bisa terjadi pada berbagai aspek lain, seperti sektor pendidikan, ekonomi, hukum, agama dan lainnya. Ketika perlakukan diskriminatif terjadi di bidang ekonomi, maka kemungkinan dampak yang akan dirasakan adalah hilangnya kesempatan berusaha dan kesulitan akses pada sumber-sumber pertumbuhan ekonomi (modal, alam, informasi, dll). Situasi diskriminasi akan menghambat penciptaan lapangan kerja. Ketenagakerjaan akan sulit berkembang ketika perlakukan disriminatif di bidang ekonomi masih berlangsung. Demikian juga bila akses pendidikan dan pengembangan Sumber Daya Manusia (SDM) tidak diberikan seluas-luasnya kepada publik, dampak selanjutnya adalah terpuruknya kualitas SDM, dan dalam jangka panjang kesempatan akan sulit diraih oleh tenaga kerja (Simanjuntak, 1985). .

Keenam, laju pertumbuhan penduduk. Ada persoalan krusial pertumbuhan kependudukan bila tidak disertai kondisi yang baik diantaranya: (a) tidak diimbangi dengan sarana dan prasaranan pendidikan yang memadai, (b) rendahnya anggaran pendidikan, (c) rendahnya tingkat kesehatan, (d) tidak seimbang dengan laju pertumbuhan kesempatan kerja, (e) rendahnya pembentukan modal, (f) rendahnya kualitas tenaga kependidikan, (g) rendahnya balas jasa di sektor pendidikan (gaji, honor, jasa riset dsb), (h) rendahnya daya beli masyarakat, (i) minimnya sumberdaya ekonomi yang bisa dieksploitasi, (j) masih rendahnya pemahaman tentang arti penting pendidikan, dan $(\mathrm{k})$ rendahnya fasilitas dan kualitas kesehatan yang dibutuhkan masyarakat. Sebagian besar negara berkembang dihadapkan pada persoalan kependudukan yang serius yang pemecahannya sangat kompleks sekali (Kindleberger and Herrick, 1977).

Ketujuh, aggregate demand unemployment. Pengangguran ini muncul karena rendahnya permintaan output ekonomi, sehingga selanjutnya berdampak pada rendahnya permintaan tenaga kerja (low derived demand). Sebaliknya, bila permintaan output tinggi (high aggregate demand), bukan hanya akan menghilangkan pengangguran jenis ini, tetapi justru akan tercipta lebih banyak lagi kesempatan kerja, bahkan situasi ini dapat mengurangi pengangguran struktural dan friksional yang terjadi sebelumnya (Rose and Nicholl, 2002).

\section{Korelasi Pengangguran dan Kinerja Ekonomi}

Pengangguran dan kinerja ekonomi memiliki pengaruh timbal balik. Hubungan negatif antara kesenjangan output riil (kinerja ekonomi) dengan output potensial terhadap pengangguran digambarkan oleh hukum Okun. Okun dalam Samuelson (2005) menyatakan bahwa untuk setiap 2 persen kemerosotan Gross National Product (GNP) faktual dari GNP potensialnya, tingkat pengangguran melonjak 1 persen. Ada studi terdahulu membuktikan bahwa 
kinerja ekonomi dan tingkat pengangguran memiliki hubungan negatif yaitu bila kinerja ekonomi naik maka tingkat pengangguran menurun dan bila kinerja ekonomi menurun maka pengangguran meningkat.

Pertama, Noor et al (2007) meneliti tentang keberadaan hukum Okun di perekonomian Malaysia terkait hubungan negatif antara pengangguran dan output (GDP). Dari penelitian tersebut mereka menemukan bahwa terdapat hubungan negatif antara output dan pengangguran di mana koefisien yang diperoleh adalah -1.748 dan diketahui bahwa pengangguran merupakan salah satu faktor yang mempengaruhi perubahan output di malaysia. Uji Kausalitas granger juga menunjukkan bahwa terdapat hubungan dua arah antara variabel pengangguran dan output.

Kedua, Petkov (2008) menguji koefisien Okun di Inggris. Petkov menggunakan alat analisis Auto Regressive Distributed Lag Model (ARDL) dengan pendekatan HodrickPrescott filter (Filter HP). Pendekatan ini digunakan Petkov untuk menangkap fenomena dengan menerapkan Eroor Correction Model (ECM) untuk mendapatkan koefisien okun. Petkov membuktikan bahwa terdapat hubungan antara pertumbuhan output dan pengangguran. Namun koefisien Okun yang ditemukan Petkov nilainya berbeda dari versi asli koefisien Okun.

$$
\text { Ketiga, Arshad }
$$

menggunakan gap equation dan teknik Filter HP. Ditemukan bukti empiris bahwa terdapat hubungan negatif dan signifikan antara PDB dan pengangguran dalam jangka pendek yang menguatkan hokum Okun. Untuk jangka panjang, digunakan Uji Kointegrasi dan ECM menunjukkan bahwa PDB dan pengangguran terkointegrasi satu sama lain dalam jangka panjang.

\section{METODE PENELITIAN}

Penelitian ini memiliki lokus di Kabupaten Pati. Penelitian ini menggunakan pendekatan deskriptifkuantitatif. Variabel penelitian mencakup pengangguran berbasis $\mathrm{KK}$ dan pengangguran berbasis usia produktif. Data penelitian menggunakan data sekunder berasal dari dinas/instansi Dinas Kependudukan dan Catatan Sipil. Pengumpulan data dilakukan dengan menggunakan teknik observasi dokumen. Analisis data menggunakan analisis deskriptif.

\section{HASIL DAN PEMBAHASAN}

\section{Penduduk Usia Produktif dan Angkatan Kerja}

Data Disdukcapil (2015) penduduk usia produktif (15-64 th) sebanyak Kabupaten Pati akhir tahun 2015 sebanyak 905.592 orang. Usia produktif sebagian masuk kategori angkatan kerja dan sebagian lain bukan angkatan kerja. Penduduk usia produktif yang bukan angkatan kerja (tidak membutuhkan kerja) mencakup penduduk berstatus sebagai ibu rumah tangga (IRT), pelajar dan pensiun. Kumulatif usia produktif yang bukan angkatan kerja sebanyak 276.508 orang dengan rincian: (a) mengurus rumah tangga 147.185 orang; (b) usia produktif sebagai pelajar dan atau mahasiswa 127.437 orang dan (c) usia produktif berstatus sebagai pensiun sebanyak 1.886 orang.

Kemudian Penduduk usia produktif (15-64 th) yang masuk kategori angkatan kerja 629.084 orang yang meliputi: (a) angkatan kerja dan bekerja sebanyak 574.866 orang dan usia produktif yang berstatus penganggur (tidak bekerja) 54.218 orang. Eksistens penduduk usia produktif di Kabuapen Pati ditunjukkan Tabel 1. 
Tabel 1.

Eksistensi dan Distribusi Usia Produktif di Kabupaten Pati Tahun 2015

\begin{tabular}{rlrrrrrr}
\hline No & Kecamatan & $\begin{array}{r}\text { Ibu } \\
\text { R.tangga }\end{array}$ & $\begin{array}{c}\text { Pelajar } \\
\text { /Mhs }\end{array}$ & $\begin{array}{c}\text { Pensiun } \\
\text { U } \leq 64\end{array}$ & $\begin{array}{c}\text { Kerja } \\
(15-64 \text { th })\end{array}$ & $\begin{array}{c}\text { Tidak } \\
\text { Kerja }\end{array}$ & $\begin{array}{c}\text { Usia } \\
\text { Prod. }\end{array}$ \\
\hline 1 & Sukolilo & 6.561 & 6.187 & 21 & 40.669 & 6.661 & 60.099 \\
2 & Kayen & 8.069 & 8.858 & 37 & 31.766 & 2.824 & 51.554 \\
3 & Tambakromo & 4.641 & 4.745 & 40 & 25.952 & 2.080 & 37.458 \\
4 & Winong & 5.825 & 5.848 & 52 & 28.656 & 2.637 & 43.018 \\
5 & Pucakwangi & 2.933 & 3.370 & 39 & 23.122 & 2.595 & 32.059 \\
6 & Jaken & 5.179 & 3.747 & 28 & 21.414 & 2.001 & 32.369 \\
7 & Batangan & 7.018 & 3.499 & 23 & 18.964 & 1.310 & 30.814 \\
8 & Juwana & 14.678 & 11.018 & 57 & 37.939 & 1.723 & 65.415 \\
9 & Jakenan & 3.554 & 5.074 & 28 & 23.243 & 1.034 & 32.933 \\
10 & Pati & 11.735 & 12.786 & 844 & 46.935 & 4.020 & 76.320 \\
11 & Gabus & 4.557 & 5.975 & 38 & 29.779 & 2.332 & 42.681 \\
12 & Margorejo & 4.566 & 5.686 & 181 & 30.179 & 2.082 & 42.694 \\
13 & Gembong & 6.584 & 4.735 & 63 & 19.342 & 2.435 & 33.159 \\
14 & Tlogowungu & 6.315 & 4.771 & 56 & 23.446 & 2.419 & 37.007 \\
15 & Wedarijaksa & 6.860 & 5.694 & 72 & 28.604 & 2.674 & 43.904 \\
16 & Trangkil & 6.850 & 7.127 & 60 & 27.401 & 1.887 & 43.325 \\
17 & Margoyoso & 9.202 & 6.290 & 54 & 30.578 & 5.098 & 51.222 \\
18 & Gn.wungkal & 2.998 & 3.027 & 12 & 19.236 & 1.467 & 26.740 \\
19 & Cluwak & 7.367 & 4.169 & 37 & 18.951 & 2.111 & 32.635 \\
20 & Tayu & 11.081 & 8.083 & 96 & 26.621 & 3.219 & 49.100 \\
21 & Dukuhseti & 10.612 & 6.748 & 48 & 22.069 & 1.609 & 41.086 \\
\hline & Kab. Pati & 147.185 & 127.437 & 1.886 & 574.866 & 54.218 & 905.592 \\
\hline
\end{tabular}

Sumber: Disdukcapil Kabupaten Pati (2015)

\section{Eksistensi Pengangguran Berbasis Usia Produktif}

Disdukcapil (2015) menyatakan bahwa penduduk usia produktif (15-64 th) sebanyak 905.592 orang dan penduduk usia produktif yang tidak membutuhkan kerja yang berstatus sebagai ibu rumah tangga, pelajar dan pensiun sebanyak 276.508 orang. Kemudian Penduduk usia produktif yang membutuhkan kerja sebanyak 629.084 orang. Sebagian Penduduk usia produktif yang membutuhkan kerja dalam status belum/tidak mendapatkan kerja sehingga menganggur sebanyak 54.218 orang. Ini berarti agregat proporsi pengangguran berbasis usia produktif sebesar $8,62 \%$. Kondisi pengangguran berdasarkan penduduk usia produktif ditunjukkan Tabel 2. 
Tabel 2.

Pengangguran Berbasis Usia Produktif di Kabupaten Pati Tahun 2015

\begin{tabular}{rlrrrrrr}
\hline No & Kecamatan & $\begin{array}{c}\text { Usia } \\
\text { Prod. }\end{array}$ & $\begin{array}{r}\text { IRT,Pljr } \\
\text { Pensiun }\end{array}$ & $\begin{array}{c}\text { Butuh } \\
\text { Kerja }\end{array}$ & $\begin{array}{c}\text { Kerja } \\
\text { (Juml) }\end{array}$ & $\begin{array}{c}\text { Tidak } \\
\text { Kerja }\end{array}$ & $\begin{array}{r}\% \\
\text { Penganggur }\end{array}$ \\
\hline 1 & Sukolilo & 60.099 & 12.769 & 47.330 & 40.669 & 6.661 & 14,07 \\
2 & Kayen & 51.554 & 16.964 & 34.590 & 31.766 & 2.824 & 8,16 \\
3 & Tambakromo & 37.458 & 9.426 & 28.032 & 25.952 & 2.080 & 7,42 \\
4 & Winong & 43.018 & 11.725 & 31.293 & 28.656 & 2.637 & 8,43 \\
5 & Pucakwangi & 32.059 & 6.342 & 25.717 & 23.122 & 2.595 & 10,09 \\
6 & Jaken & 32.369 & 8.954 & 23.415 & 21.414 & 2.001 & 8,55 \\
7 & Batangan & 30.814 & 10.540 & 20.274 & 18.964 & 1.310 & 6,46 \\
8 & Juwana & 65.415 & 25.753 & 39.662 & 37.939 & 1.723 & 4,34 \\
9 & Jakenan & 32.933 & 8.656 & 24.277 & 23.243 & 1.034 & 4,26 \\
10 & Pati & 76.320 & 25.365 & 50.955 & 46.935 & 4.020 & 7,89 \\
11 & Gabus & 42.681 & 10.570 & 32.111 & 29.779 & 2.332 & 7,26 \\
12 & Margorejo & 42.694 & 10.433 & 32.261 & 30.179 & 2.082 & 6,45 \\
13 & Gembong & 33.159 & 11.382 & 21.777 & 19.342 & 2.435 & 11,18 \\
14 & Tlogowungu & 37.007 & 11.142 & 25.865 & 23.446 & 2.419 & 9,35 \\
15 & Wedarijaksa & 43.904 & 12.626 & 31.278 & 28.604 & 2.674 & 8,55 \\
16 & Trangkil & 43.325 & 14.037 & 29.288 & 27.401 & 1.887 & 6,44 \\
17 & Margoyoso & 51.222 & 15.546 & 35.676 & 30.578 & 5.098 & 14,29 \\
18 & Gn.wungkal & 26.740 & 6.037 & 20.703 & 19.236 & 1.467 & 7,09 \\
19 & Cluwak & 32.635 & 11.573 & 21.062 & 18.951 & 2.111 & 10,02 \\
20 & Tayu & 49.100 & 19.260 & 29.840 & 26.621 & 3.219 & 10,79 \\
21 & Dukuhseti & 41.086 & 17.408 & 23.678 & 22.069 & 1.609 & 6,80 \\
\hline & Kab. Pati & 905.592 & 276.508 & 629.084 & 574.866 & 54.218 & 8,62 \\
\hline Sumber
\end{tabular}

Sumber : Disdukcapil Kabupaten Pati (2015)

Berdasarkan usia produktif, proporsi pengangguran tertinggi berada di Kecamatan Margoyoso disusul Kecamatan Sukolilo dan Kecamatan Gembong. Kecamatan Margoyoso memiliki angkatan kerja (butuh kerja) sebanyak 35.676 orang dan angkatan kerja menganggur sebanyak 5.098 orang maka tingkat pengangguran $14,29 \%$. Kecamatan Sukolilo memiliki angkatan kerja (butuh kerja) sebanyak 47.330 orang dan angkatan kerja menganggur sebanyak 6.661 orang maka tingkat pengangguran $14,07 \%$. Selanjutnya Kecamatan Gembong memiliki angkatan kerja (butuh kerja) sebanyak 21.777 orang dan angkatan kerja menganggur sebanyak 2.435 orang maka tingkat pengangguran $11,18 \%$.

\section{Eksistensi Pengangguran Berbasis Kepala Keluarga}

Kabupaten Pati memiliki 21 kecamatan dengan kumulatif jumlah KK sebanyak 423.638 (Disdukcapil, 2015). Kepala Keluarga (KK) yang tidak membutuhkan kerja yang berstatus sebagai ibu rumah tangga (IRT), pelajar dan pensiun sebanyak 22.198. Kemudian Kepala keluarga (KK) yang membutuhkan kerja sebanyak 401.440 
KK dengan rincian: (a) Kepala keluarga yang bekerja sebanyak 393.177 KK dan Kepala keluarga yang tidak bekerja sebanyak 8.263 KK.

Sebagian Kepala keluarga (KK) yang membutuhkan kerja dan berstatus belum/tidak mendapatkan kerja sehingga menganggur sebanyak 8.263 KK. Ini berarti proporsi pengangguran berbasis KK sebesar 2,06 \% yang berasal dari $(8.263 / 401.440) \times 100 \%)$.

Tabel 3.

Pengangguran Berbasis Kepala Keluarga di Kabupaten Pati Tahun 2015

\begin{tabular}{rlrrrrrr}
\hline No & Kecamatan & Juml & IRT,Pljr & KK & KK Tdk & Butuh & \% KK \\
& & KK & Pensiun & Kerja & Kerja & Kerja & Nganggur \\
\hline 1 & Sukolilo & 26.253 & 681 & 25.325 & 247 & 25.572 & 0,97 \\
2 & Kayen & 23.175 & 1.239 & 21.442 & 494 & 21.936 & 2,25 \\
3 & Tambakromo & 17.377 & 651 & 16.533 & 193 & 16.726 & 1,15 \\
4 & Winong & 20.882 & 981 & 19.551 & 350 & 19.901 & 1,76 \\
5 & Pucakwangi & 15.058 & 491 & 14.369 & 198 & 14.567 & 1,36 \\
6 & Jaken & 15.885 & 574 & 15.016 & 295 & 15.311 & 1,93 \\
7 & Batangan & 14.946 & 666 & 14.015 & 265 & 14.280 & 1,86 \\
8 & Juwana & 30.433 & 1.693 & 28.004 & 736 & 28.740 & 2,56 \\
9 & Jakenan & 16.360 & 532 & 15.637 & 191 & 15.828 & 1,21 \\
10 & Pati & 36.323 & 4.027 & 31.240 & 1.056 & 32.296 & 3,27 \\
11 & Gabus & 20.003 & 691 & 18.985 & 327 & 19.312 & 1,69 \\
12 & Margorejo & 20.101 & 930 & 18.806 & 365 & 19.171 & 1,90 \\
13 & Gembong & 15.092 & 769 & 14.003 & 320 & 14.323 & 2,23 \\
14 & Tlogowungu & 17.414 & 808 & 16.324 & 282 & 16.606 & 1,70 \\
15 & Wedarijaksa & 20.185 & 1.046 & 18.642 & 497 & 19.139 & 2,60 \\
16 & Trangkil & 20.239 & 884 & 18.740 & 615 & 19.355 & 3,18 \\
17 & Margoyoso & 23.768 & 1.340 & 21.829 & 599 & 22.428 & 2,67 \\
18 & Gn.wungkal & 12.179 & 268 & 11.790 & 121 & 11.911 & 1,02 \\
19 & Cluwak & 15.694 & 921 & 14.608 & 165 & 14.773 & 1,12 \\
20 & Tayu & 23.027 & 1.674 & 20.684 & 669 & 21.353 & 3,13 \\
21 & Dukuhseti & 19.244 & 1.332 & 17.634 & 247 & 17.912 & 1,55 \\
\hline & Kab. Pati & 423.638 & 22.198 & 393.177 & 8.263 & 401.440 & 2,06 \\
\hline
\end{tabular}

Sumber : Disdukcapil Kabupaten Pati (2015)

\section{Upaya Mereduksi Pengangguran Melalui Permintaan Tenaga Kerja}

Upaya mengatasi pengangguran lewat jalur permintaan tenaga kerja (demand for labour) yaitu melalui penciptaan lapangan kerja baru secara langsung. Potensi solusi Penanggulangan pengangguran melalui permintaan tenaga kerja bisa dilakukan dengan berbagai opsi yang potensial untuk menjadi solusi pengangguran.
Pertama,

optimalisasi pemanfaatan sumberdaya alam (lahan). Hal ini bisa dilakukan apabila masyarakat diberi peluang (akses) terhadap penguasaan (paling tidak) penggarapan lahan (publik). Tidak hanya sampai di situ, pemerintah pun harus memberikan fasilitasi yang kondusif agar masyarakat mampu mengelola lahan dengan optimal dan aman karena kepastian hukumnya jelas. 
Kedua, peningkatan akses terhadap sumber-sumber modal. Akses pada sumber modal sangat menentukan bagi pengembangan usaha sekaligus kesempatan kerja. Ketika kemudahankemudahan diciptakan untuk masyarakat lapisan bawah, dan pembinaan dilakukan, maka potensi usaha ekonomi masyarakat akan berkembang.

Ketiga, peningkatan investasi atau pembentukan modal (capital formation). Investasi bisa bersumber dari pihak internal maupun eksternal. Dari internal bisa didapat lewat pemupukan tabungan masyarakat dan dari eksternal melalui peningkatan arus investasi (penanaman modal) dari pihak luar. Bila dua sumber ini lancar dan kenaikannya signifikan, maka ada potensi peningkatan aktivitas usaha ekonomi dan memiliki pengaruh positif terhadap permintaan tenaga kerja (kesempatan kerja).

Keempat, kerjasama pihak terkait (stakeholders). Kerjasama berbagai pihak sangat bergantung pada kredibilitas pemerintah, situasi objektif domestik seperti: peluang pasar, potensi wilayah, keamanan, politik dan kelembagaan yang mendukung sistem pemerintahan. Bila berbagai faktor tersebut kondusif, maka investor cenderung siap melakukan kerjasama pengembangan wilayah sehingga ada potensi dampak pada pertumbuhan ekonomi daerah dan kesempatan kerja.

Kelima, perluasan pasar hasil produksi domestik. Tahap ini tercipta setelah tahap kerjasama dan arus investasi masuk ke suatu wilayah. Artinya tahap ini sebagai konsekuensi dari existing situation yang ada sebelumnya. Perluasan pasar dapat ditingkatkan dengan beberapa cara diantaranya dengan perbaikan kualitas, penguatan akses informasi, memahami prilaku pesaing, memahami kehendak buyer dan lancarnya delivery order system.
Keenam, pembinaan usaha ekonomi masyarakat. Ada ragam upaya yang bisa dilakukan dalam rangka pembinaan usaha tetapi yang paling penting dari itu semua adalah jiwa wirausaha. Pembinaan usaha ini bisa berupa pembinaan yang bernuansa administratif seperti perijinan dan dapat pula berupa peningkatan kinerja usaha seperti peningkatan proses produksi dan orientasi pemasaran.

Ketujuh, pengembangan usaha padat karya. Usaha padat karya adalah jenis karakteristik usaha yang paling cocok untuk negara berkembang yang memiliki tingkat pertumbuhan penduduk tinggi. Namun ini bukan berarti menolak semua teknologi yang terus berkembang saat ini. Teknologi tetap dibutuhkan, dengan catatan tidak akan mempersulit (mempersempit) lapangan kerja baru, ramah lingkungan, terjangkau biayanya dan adaptasinya dapat dengan mudah diserap dan diimplementasi oleh tenaga kerja domestik.

Kedelapan, kebijakan pemerintah. Suasana kondusif dapat tercipta karena pemerintah dan pemerintah daerah melakukan fasilitasi dan memberikan berbagai kemudahan (insentif ekonomi) bagi pengembangan usaha. Berbagai peraturan yang diciptakan bertujuan untuk memberikan motivasi dan semangat usaha, tidak sebaliknya (menjadikan pengusaha atau kegiatan usaha menjadi objek penghasilan semata). Pola kerja dengan pendekatan proyek (project oriented) harus diubah menjadi budaya social benefit, semua usaha yang dilakukan pemerintah tidak melulu profit seeking (memburu laba) dalam rangka mendongkrak economic growth, tetapi lebih jauh dari itu bagaimana " pertumbuhan ekonomi" itu mengalir dan bermanfaat bagi masyarakat. Kondisi ini bisa dilakukan dengan orientasi pembangunan sesuai dengan konteks lokal, misalnya 
pembangunan infrastruktur desa dengan swakelola dan mempekerjakan masyarakat setempat.

\section{Upaya Mereduksi Pengangguran Melalui Supply of Labor}

Upaya mengatasi pengangguran melalui jalur supply of labor identik dengan pengembangan sumber daya manusia (human resource development). Implementasi praktis mengatasi pengangguran melalui jalur supply of labor menurut Reynolds et al (1986) dan Ehrenberg dan Smith (1988) mencakup beberapa substansi.

Pertama, peningkatan dan penguatan pendidikan dasar dan menengah (Primary and high school education). Mekanisme yang lazim dilakukan dalam kebijakan adalah dengan penyediaan anggaran yang memadai.

Kedua, pengembangan pendidikan lanjutan dan perguruan tinggi (college and postgraduate education). Pendanaan program ini tidak menjadi kewajiban negara sepenuhnya, tetapi subsidi anggaran di sektor ini agar disediakan.

Ketiga, training provided by employers on the job. Pelatihan yang disediakan langsung oleh perusahaan terkait langsung dengan pekerjaan. Program ini merupakan kebutuhan perusahaan dalam rangka penajaman tugas pekerjaan (jobs) yang akan langsung ditangani di perusahaan yang bersangkutan. Kegiatan ini akan beragam sekali tergantung spesifikasi bidang usaha yang dikembangkan oleh perusahaan.

Keempat, accumulated of skill through continued work experience. Peningkatan keahlian melalui pengalaman kerja. Keahlian ini didapat bukan dari pendidikan formal tetapi diperoleh melalui pengalaman kerja secara langsung (learning by doing). Akumulasi pengetahuan berbasis pengalaman memiliki kedalaman yang mantap pada bidangnya dan terkonsekuensi. Upaya kearah itu dapat dilakukan dengan kombinasi antara pendidikan formal dengan terjun langsung pada bidang usaha yang relevan.

Kelima, Government training programs for displaced or disadvantaged workers. Pelatihan yang dilakukan bagi pekerja yang tergeser dan kurang beruntung. Program ini bisa dilakukan oleh pemerintah dalam rangka mempersiapakan tenaga kerja yang siap bekerja untuk mengganti tenaga kerja yang pensiun. Sebetulnya kondisi yang sama dapat juga dilakukan oleh perusahaan dalam rangka mempersiapakan tenaga kerja pengganti yang lebih produktif dan semangat baru.

Model jalur supply of labor sering menghadapi sejumlah hambatan diantaranya : (a) sulitnya mengukur kebutuhan human capital; (b) identifikasi masalah ketenagakerjaan relatif kompleks; (c) sulit diukur besar tingkat akumulasi daya serap tenaga kerja terhadap transfer of knowledge; (d) tidak mudah menentukan jenis pendidikan apa yang harus diberikan, kapan dan sejauh mana; dan (e) bagaimana mengukur hasil dari investasi pada SDM (Jhingan, 2000).

Upaya mereduksi pengangguran dapat dikaitkan dengan dengan konteks yang sedang berjalan adanya dana desa yang relatif besar dan memungkinkan sebagian dana desa digunakan untuk pemberdayaan masyarakat. Pemerintahan desa dapat melakukan pelatihan ketrampilan dalam rangka menghasilkan produk sesuai potensi lokal desa. Pemberdayaan masyarakat agar disesuaikan dengan karakteristik keunikan desa. Permendagri Nomor 51 Tahun 2007 tentang Pembangunan 
Kawasan Pedesaan Berbasis Masyarakat, Pasal 16 menyatakan bahwa sasaran penguatan kapasitas masyarakat meliputi komunitas kawasan: (a) perdesaan terpencil; (b) perdesaan tertinggal; (c) perdesaan pesisir pantai; (d) perdesaan di pinggir hutan; (e) perdesaan dataran tinggi; (f) perdesaan daerah aliran sungai dst. Pemberdayaan masyarakat agar mengedepankan potensi lokal desa. Pemberdayaan masyarakat akan berjalan baik jika ada kebijakan lokal daerah yang relevan sehingga ada harapan tercipta usaha ekonomi masyarakat tumbuh dan berkembang maka ada perluasan lapangan kerja dan penyerapan tenaga kerja yang berdampak pada reduksi pengangguran.

\section{KESIMPULAN}

Pertama, pengangguran merupakan salah satu masalah serius dalam pembangunan. Kedua, pengangguran dapat disebabkan berbagai faktor determinan. Ketiga, pengangguran memiliki potensi dampak negatif diberbagai sektor sosial masyarakat. Keempat, tingkat pengangguran berdasarkan usia produktif (15-64 th) di Kabupaten Pati sebesar 8,62\%. Kelima, tingkat pengangguran berdasarkan kepala keluarga (KK) di Kabupaten Pati sebesar $2,08 \%$.

Guna mereduksi pengangguran maka perlu dilakukan upaya-upaya yang relevan. Pertama, upaya mengatasi pengangguran lewat jalur permintaan tenaga kerja (demand for labour) yaitu melalui penciptaan lapangan kerja baru. Kedua, upaya mengatasi pengangguran melalui jalur supply of labor yang identik dengan pengembangan sumber daya manusia (human resource development) agar memiliki kapasitas sesuai dengan kebutuhan pasar tenaga kerja. Ketiga, optimalisasi peran desa dalam pemberdayaan masyarakat untuk mengembangkan wirausaha atau menjadi tenaga kerja dalam pembangunan desa.

\section{DAFTAR PUSTAKA}

Arshad, Z. 2010. The Validity of Okun's Law in the Swedish Economy. Stockholm : Departement of Economics Stockholm University.

Ehrenberg, R.G. and R.S. Smith, 1988. Modern Labor Economics : Theory and Public Policy. Third Edition. Boston : Scott, Foresman and Company.

Gordon, R.J. 1993. Macroeconomics. Sixth Edition. New York : HarperCollins Publishers.

Jhingan, M.L. 2000. Ekonomi Pembangunan dan Perencanaan. Jakarta : PT RajaGrafindo Persada.

Kindleberger, C.P. and B. Herrick. 1977. Economic Development. International Student Edition. Tokyo : Mc Graw Hill Kogakusha Ltd.

Noor, Z. M., N. M. Nor, A. G. Judhiana. 2007. The Relationship Between Output and Unemployment in Malaysia: Does Okun's Law Exist? International Journal of Economics and Management, Vol 1(3) : 337-344.

Peraturan Menteri Dalam Negeri Republik Indonesia. 2007 Tentang Pembangunan Kawasan Perdesaan Berbasis Masyarakat.

Petkov, B. 2008. The Labour Market and Output in the UK - Does Okun's Law Still Stand?. Sofia : Bulgarian National Bank

Samuelson, P. A. dan W. D. Nordhaus. 2005. Ekonomics. New York: McGraw Hill. 
Simanjuntak, P. J. 1985. Pengantar Ekonomi Sumber Daya Manusia. Jakarta : Lembaga Penerbit Fakultas Ekonomi Universitas Indonesia.

Reynolds, L.G., S.H. Masters and C.H. Moser. 1986. Labor Economics and Labor Relations. Ninth Edition. New Jersey : PrenticeHall, Englewood Cliffs.

Rose, C. and M. J. Nicholl. 2002. Accelerated Learning for The $21^{\text {st }}$ Century. Terjemahan. Bandung : Yayasan Nuansa Cendikia.

Sukirno. 2004. Makroekonomi Teori Pengantar. Edisi Ketiga. Jakarta : Penerbit Raja Grafindo Persada.
Sukirno, Sadono. 1985. Ekonomi Pembangunan. Jakarta : Lembaga Penerbit Fakultas Ekonomi Universitas Indonesia

Undang-Undang Dasar Negara Republik Indonesia Tahun 1945

Undang-Undang Republik Indonesia Nomor 13 Tahun 2003 tentang Ketenagakerjaan

\section{BIODATA PENULIS}

Suroso, lahir 19 Maret 1966 di Kabupaten Pati Jawa Tengah. Magister Perencanaan Kota dan Daerah Universitas Gajah Mada. Bekerja di Kantor Penelitian dan Pengembangan Kabupaten Pati sebagai Peneliti Madya. 